\title{
NAKI ISANBET, A TRANSLATOR OF RUSSIAN CLASSICAL LITERATURE
}

\author{
Rinat Ferganovich Bekmetov, \\ Kazan Federal University, \\ 18 Kremlyovskaya Str., Kazan, 420008, Russian Federation, \\ bekmetov@list.ru.
}

\begin{abstract}
The article deals with the translation activity of Naki Isanbet. Our analysis is based on his translations of Russian classical literary works, in particular, some fragments from "The Fountain of Bakhchisaray" and "Poltava" by A. S. Pushkin. The article discusses the issues of cultural and ideological context of the appeal to Russian classics, technical innovations as compared to the predecessors, and the problems related to the principles of professional translation work. The important elements of Naki Isanbet's style as a translator are his accuracy in transmitting the meaning of the original, the compliance of the new translated text with the norms of the native (Tatar) language, his aesthetic techniques and the depth of penetration into the imaginary world of Russian literature. The topic, without any doubt, requires further research.
\end{abstract}

Key words: Naki Isanbet, Russian literature, Tatar language, literary translation, comparison and contrast, semantic transformations.

Among the extensive creative heritage of Naki Isanbet, literary translations occupy a special place. This aspect of his activity is well known, but its scientific and philological understanding was and, alas, still is very sporadic, it is far from being systematic: it is not enough to point to a particular translation of $\mathrm{N}$. Isanbet in the aspect of a simple factual statement, as it is done sometimes - it is important to understand what artistic strategy he followed, recreating the image of another culture in his native language, what the socio-historical context of his work was like, what principles of selecting material for translation he followed, finally, how the author's novelty was designated. Of course, it is not possible to fully cover these issues within the limits of a small article.

In the history of Tatar translation (which, by the way, has yet to be written), N. Isanbet is an exceptional figure and a milestone. So far, we can state that there exist numerous articles and materials devoted to this problem ([Avrutin, Khabutdinov], [Galiullin, Khabutdinova], [Nagumanova], [Saifullin, Valeeva], etc.). Hence, to make the study of the topic complete, it would be necessary to involve different sources, starting with the author's manuscript fund, so that it would be possible to trace in detail the evolution of the translator's idea (the idea, even if unconsciously, is always there), the technique of processing the original in a specific lexical-semantic and communicative-syntactic key, and finally, a general overview of the state of translation among the Tatars of the
Volga-Ural Region, including the period when $\mathrm{N}$. Isanbet began to translate the works of foreign writers. Our goal is much more modest: it is to show what fundamental approaches $\mathrm{N}$. Isanbet used in the process of transferring the meanings of the Russian figurative and literary word into the Tatar language.

Generally speaking, N. Isanbet was engaged in translating masterpieces of world literature - not only Russian, but also Western and Eastern, and in the latter cases he turned to the originals. It was a fully conscious attitude of $\mathrm{N}$. Isanbet - the heir of the traditions of the early $20^{\text {th }}$ century, the era of the cultural rise of the Tatar nation. Thus, some biographical indexes emphasize that N. Isanbet's work on "Hamlet", translated by him in the 1940s, was preceded by a special study of the English language [Odiplərebez: biobibliografik beleshməlek, p. 613], in order to achieve a more accurate and verified dialogue with the worldfamous dramatist and the text written by him, not mediated by a Russian translation ${ }^{1}$.

[1] His path, chosen at that time, was not an easy one, which, by the way, once again and without false pathos characterizes N. Isanbet as a great, truly "epic" laborer who was clearly aware of his own task and honestly carried it out, despite numerous "tactical" obstacles. In the era of $\mathrm{N}$. Isanbet, there was a widely spread and quickly implemented view that non-Russian peoples of the Soviet Union (the Tatars have used the Cyrillic alphabet since May, 1939) were to get acquainted with the samples of world literature in translations from Rus- 
sian, and not from foreign languages, not directly. The teaching of foreign languages was quite scholastic at that time, grammar-oriented, little and poorly connected with the practice of live communication, the language that today can be called "the Soviet dialect" of English, German or French. In fact, an "internal" foreign language was created, a bookish language by nature and a home language by the sphere of use, a product of state isolationism. Naturally, in this truncated form, languages were not mastered to a required degree. The Russian translation school was represented by the names of poets and prose writers who knew the language not only because of their undoubted linguistic talent, but often because they had a unique opportunity (such as S. Marshak, K. Chukovsky, or M. Lozinsky) to go abroad in their youth, to see and learn another world. N. Isanbet, like many Soviet Tatar translators was deprived of such opportunity, unlike Sh. Mudarris, who saw Europe by the will of fate as a participant of the Great Patriotic War (at the beginning of the $20^{\text {th }}$ century Tatar poets, the sons of wealthy merchants while visiting Western countries used to bring foreign books and translate them at home, without resorting to the help of intermediary languages). Now, it is clear what incredible efforts translators had to make to correctly understand the semantic side of the original. M. Maksud, translating the story "Cola Bryunon" by R. Rolland from French asked M. Lozinsky to clarify certain places: both were the members of the Writers' Union. Whether N. Isanbet addressed the latter while working on "Hamlet" we cannot say for sure. By comparing two translations of the tragedy, Russian and Tatar, we find some discrepancies: considering M. Lozinsky's opinion of the translation, N. Isanbet went his own way, taking into account the laws of his native Tatar language (see: [Bekmetov, Spirchagova]).

From the Russian Literature Fund, he productively translated the classics of the $19^{\text {th }}$ century, its first half. The bibliography of these translations is not long: it includes two authors and four essays. Here are the names and works of Russian writers translated by N. Isanbet:

1) A. S. Griboyedov: the comedy "Woe from Wit" [Griboedov, 1945], [Griboedov, 1946];

2) A. S. Pushkin: poems "The Fountain of Bakhchisaray" [Pushkin. Bakchasarai fontany, 1937, No. 1], [Pushkin. Bakchasarai fontany, 1937] and "Poltava" [Pushkin. Poltava, 1937], [Pushkin, 1950], tragedy "The Stone Guest" [Pushkin. Tash Kunak, 1937], [Pushkin, 1949], [Pushkin, 1954].

Let's briefly review the translations of two A. Pushkin's poems - "The Fountain of Bakhchisaray" and "Poltava". Translations of A. Griboyedov and A. Pushkin's dramatic works need to be considered separately, because they embody a very special, scenic logic of the images of characters and objects, which N. Isanbet, a sophis- ticated connoisseur of theatrical art, knew and used perfectly well; we will not consider them here.

So, the famous poems by A. Pushkin...

The fact that they were translated into Tatar was due to two main circumstances: the social order and the intra-literary situation.

In fact, in 1937, the Soviet Union celebrated the $100^{\text {th }}$ anniversary of A. Pushkin's death on a grand scale. Like every phenomenon of that period, this event included an ideological component with the elements of Stalinist myth-making era: A. S. Pushkin was recognized as almost the only poet in the sky of the classical century (for proletarian culture V. V. Mayakovsky played a similar role), although a more objective interpretation of the A. Pushkin myth required, among other things, taking into account the significance of the Western cultural ground, against which the poet could appear as a phenomenon of a grand "leap" that "accelerated" the development of Russian literature ${ }^{2}$.

[2] This indicates the multi-vector, versatile nature of Russian classics, which excludes one-sided monologism of ideas and style. Isn't F. Tyutchev on a par with A. Pushkin, his original lyrics found a full response in the early $20^{\text {th }}$ century, and its author was described in the articles of that time as a forerunner of symbolism, "Russian Goethe"?

This was the all-Soviet trend - to single out one bright figure of the aesthetic process and call it the representative of national aspirations (ideals and hopes). This rule applied both to Russian literature and the literatures of the peoples of the USSR: in Ukrainian literature the cult of propagandized and socially encouraged love was absorbed by Taras Shevchenko, in Kazakh - Abay (Ibrahim) Kunanbayev and Dzhambul Jabayev, in Tatar - Gabdulla Tukay [Frederik], [Giliazov, 2010], [Giliazov, 2013] (in the post-war years Musa Jalil), in Turkmen - Makhtumkuli, the list can be continued... Their works were published in unthinkably huge editions by modern standards (both in popular and academic series), translated into the languages of the world (all translations of A. Pushkin by N. Isanbet were published in 1937), individual articles and collective monographs were written about them - in short, a powerful ideological machine, regardless of material and financial expenses, created a factory for the production of "sacred" meanings, and translators took an active part in it. N. Isanbet was no exception ${ }^{3}$.

It is well known that during the period of renovation in the social and cultural life of the Tatars, newspaper editorial teams created translation 
clubs, which led to the formation of a "new generation of translators: S. Rakhmankoly, I. Bogdanov, V. Akhmadullin, G. Keram, V. Apanaev, and I. Kazakov. Along with them, writers G. Tukay, F. Amirkhan, G. Kamal, S. Ramiev, G. Iskhaki, and G. Rakhim actively joined in" [Nagumanova, p. 73]. The increase in the number of translated works inspired Tatar scientists to study the theoretical foundations of translation activities, their types, principles and techniques, which resulted in the systematization of what had been learned and gained in this area. In particular, the researchers highly appreciated G. Tukay's skill of translator, who raised translation to a high artistic level [Galiullin, Khabutdinova, pp. 56-57].

In the first third of the twentieth century, the famous Tatar writer and literary critic G. Ibragimov recommended that the works for translation should be selected taking into account their positive effect on the national psychology of the Tatars and their public consciousness, healing wounds and promoting the pleasure of reading. Scholars and public figures spoke highly of S. Suncheley, who translated A. Pushkin's "Prophet", G. Byron's "Corsair", and G. Heine's "Almanzor" into Tatar, who introduced the Tatars to the heritage of famous Oriental and Arab writers, previously inaccessible to them. [Ibragimov, 2019], [Kazanly]. At the same time, the poet was criticized for his striving to tatar a number of works, especially "Almanzor"; such a gross interference in the original was characterized as a "literary crime" [Ibragimov, 2019, p. 67]. Obviously, in the 1910s, scientific and critical thought set serious requirements for the literary work of this kind. Thus, came the understanding of European and Russian writers as well as the artistic-aesthetic value of their works.

[3] It is necessary to explain that the writers, whose works were translated, were undoubtedly worthy of praise. Who will argue with the fact that A. S. Pushkin is "our everything"? The problem was that by bringing one individual to the foreground on the basis of their national origin (or sympathy for the masses), Soviet ideology simplified cultures that had existed for centuries. G. Tukay was great, but besides him Tatar literature had an elite, an aristocratic vector of the movement in the person of Derdmend who was enrolled in the category of "national-bourgeois elements", that was "socially alien". M. Jalil was included in the pantheon of Soviet heroes, thanks to which his work received a very positive assessment. Meanwhile, an unassuming acquaintance with the early works of the poet convinces us how unperfect they are in comparison, for example, with his "Moabite Notebooks" - the fruit of really spiritual tension and volitional efforts on the verge of death.

And this attempt of the Soviet government to artificially cultivate a poet with a given thematic line focused on urgent social problems, as happened in the case of Dzhambul, which cannot but lead to questions of a rather specific nature (much of what this steppe akyn wrote, as it now turns out, did not belong to him by right of authorship; most of his texts were created first by a team of Russian poets in the style of ordinary Kazakh chants, and then translated by Dzhambul into his native language by compressed retellings-explanations of people from his closest circle; all this was issued as translations from Kazakh [Dzhambul Dzhabaev]).

On the other hand, the attitude to the genius of A. Pushkin among Tatar intellectuals was most reverent, starting from the first acquaintance in the late $19^{\text {th }}$ - early $20^{\text {th }}$ century. There was a kind of Tatar Pushkiniana, represented primarily by translations of A. Pushkin's works, free transcriptions of his poems; the cult of Tatar worship of the top Russian classics developed, it was a logical response to the installation of jadidism, introduced in new-fashioned schools, (the Russian language was recognized as the language of high enlightenment, which opened the doors to science, art, and public life). Of course, not everything was chosen for translation - only the works which were related in terms of cultural, geographical and religious realities. Thus, from M. Lermontov they preferred to translate either the Turkish fairy tale "AshikKerib" or "Bela", violating the integrity of the novel and neglecting other stories in "The Hero of Our Time": the fate of a young and inexperienced Muslim Princess, sympathetically described by the Russian poet, could not fail to provoke intense interest, which evoke sentimental reflections on the female destiny (it is noteworthy that N. Karamzin's "Poor Liza" was arbitrarily translated with changes in the names of characters, its plot and settings, bringing them closer to the Tatars, adapting them to their native, lived-in reality); also Leo Tolstoy's Caucasian story "Hadji Murad" with its ethically colored pathos of proud and uncompromising resistance to any power. They were translated many times, books-pamphlets sold out quickly, and they were, by the way, inexpensive. So, N. Isanbet translated A. Pushkin, beloved by all Tatars, taking into account the work of his predecessors.

Probably, he translated "Poltava" by order through editorial selection: first of all, the established ideological monism of the 1930s had a monumental interpretation of Russian history, and it was necessary to broadcast it to the non-Russian peoples of the USSR, secondly, the plans of the 
national branches of the Union of writers included the task of large-scale acquaintance with the great poet, this task included the publication of previously untranslated works of A. Pushkin in the Tatar language. As for "The Fountain of Bakhchisaray", this southern poem had been translated before $\mathrm{N}$. Isanbet, moreover, they could not help but translate it, since the object of the image here was the Crimea, which had historical ties with the Volga Tatars at the beginning of the formation of the Kazan khanate after the collapse of the Golden Horde and their peak was during the Girey dynasty on the Kazan throne ("Crimean party"). In 18991900 , A. Pushkin's poem was translated by $\mathrm{Mu}-$ hammad-Salim Umetbayev, and it was published in the private printing house of B. L. Dombrovsky in Kazan, as expected, after checking and issuing a special censorship permit from St. Petersburg, dated November 27, 1900 [Pushkin, 1901] .

[4] Umetbaev Muhammad-Salim Ishmuhametovich (1841-1907) - a famous Bashkir enlightener, poet, translator, philologist, ethnographer, public figure, a member of the Orenburg branch of the Russian geographical society, also a member of the official Commission of A.S. Pushkin's $100^{\text {th }}$ birthday anniversary celebration, besides he was a member of the Crimean Commission of the Ministry of Internal Affairs of Russia on Waqf (in Islam - property) cases. About him and his work, scientific and literary, see: [Umetbayev, p. 562]. The word "Bashkir" appears as a unit of a marked row on the cover of the publication of the poem before the name and surname of the translator (cf. "mutarzema: Bashkort Mukhammadsalim Umutbayev").

It is reasonable to compare the selected lines from the two translations of the "The Fountain of Bakhchisaray". Let's take one passage - the beginning of A. Pushkin's poem, which shows Girey the head of a powerful state:

\begin{tabular}{|c|c|c|}
\hline $\begin{array}{c}\text { А. С. Пушкин. } \\
\text { «Бахчисарайский } \\
\text { фонтан» }\end{array}$ & $\begin{array}{c}\text { Translated by } \\
\text { Salim Umetbaev } \\
\text { (1900) } \\
\text { («Багъчасарай } \\
\text { фонтаны») }\end{array}$ & $\begin{array}{c}\text { Translated by } \\
\text { Naki Isanbet } \\
\text { (1937) } \\
\text { («Бакчасарай } \\
\text { фонтаны») }\end{array}$ \\
\hline $\begin{array}{l}\text { 1. Гирей сидел, } \\
\text { потупя взор; } \\
\text { 2. Янтарь в устах } \\
\text { его дымился; } \\
\text { 3. Безмолвно } \\
\text { раболепный двор } \\
\text { 4. Вкруг хана } \\
\text { грозного } \\
\text { теснился. } \\
\text { 5. Все было тихо } \\
\text { во дворце; }\end{array}$ & $\begin{array}{l}\text { 1. Ултырып } \\
\text { (утыра) } \\
\text { Багъчасарайда } \\
\text { (Бахчасарайда), } \\
\text { / Түбән карап } \\
\text { Гәрәй хан. } \\
\text { 2. Авыздагы } \\
\text { янтарьдан / } \\
\text { Уйнадыр } \\
\text { (уйната) иде } \\
\text { дәхан (төтен); }\end{array}$ & $\begin{array}{l}\text { 1. Гәрәй утыра } \\
\text { иде карап } \\
\text { түбән, } \\
\text { 2. Хур-хур төти } \\
\text { иде авызында; } \\
\text { 3. Якыннары } \\
\text { колдай башын } \\
\text { игән, } \\
\text { 4. Сыенып } \\
\text { дәһшәтле хан } \\
\text { алдында. }\end{array}$ \\
\hline
\end{tabular}

\begin{tabular}{|c|c|c|}
\hline $\begin{array}{l}\text { 6. Благоговея, все } \\
\text { читали } \\
\text { 7. Приметы гнева } \\
\text { и печали } \\
\text { 8. На сумрачном } \\
\text { его лице. } \\
\text { 9. Но повелитель } \\
\text { горделивый } \\
\text { 10. Махнул рукой } \\
\text { нетерпеливой: } \\
\text { 11. И все, } \\
\text { склонившись, } \\
\text { идут вон [Пуш- } \\
\text { кин, 1986, с. 48]. }\end{array}$ & 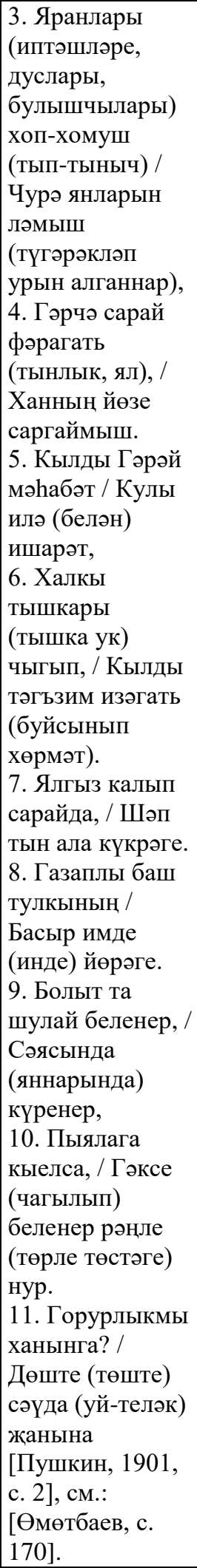 & $\begin{array}{l}\text { 5. Бар да тып- } \\
\text { тын иде бу } \\
\text { сарайда; } \\
\text { 6. Зурлап аны } \\
\text { ихлас күңелдән, } \\
\text { 7. Ачу, кайгы } \\
\text { эзен алар бар да } \\
\text { 8. Укый аның } \\
\text { сүнгән } \\
\text { йөзеннән. } \\
\text { 9. Ләкин } \\
\text { мәгърур хаким } \\
\text { түзмәде, } \\
\text { 10. Кулын гына } \\
\text { селтәп жибәрде, } \\
\text { 11. Бар да иелеп } \\
\text { тышка тотты юл } \\
\text { [Пушкин, 1950, } \\
\text { с. 63]. }\end{array}$ \\
\hline
\end{tabular}

Giray sat with his eyes downcast;

An amber was smoking in his mouth;

Silently the fawning court

Was swarming round the formidable Khan.

All was quiet in the palace;

Reverentially, all read 
The signs of anger and sadness

On his gloomy face.

But the proud master

Waved his impatient hand:

And all, bending, went out [literal translation].

The translation of S. Umetbayev into the Turkic language is adaptive, embedded in the poetics of classical Turkic-Tatar (wider - Eastern) versification. The lines are divided into half-verses, and paired rhyming is more often used, including within half-verses, to maintain ease in rhythmic drawing. The text style is based on an explanation of the episode (in case of violation of linear correspondences: for example, line 11 of the original is line 6 of the translation). A. Pushkin's beginning contains a romantic riddle: the poet recreates the picture of silence in the Palace, caused by Girey's excitement. The reason for this state is not mentioned in the fragment: the author shrouds the story in a fog, a veil of mystery; through a set of rhetorical questions in the third stanza, he makes the reader think (and with the reader he thinks himself) about what could have caused the "gloom" of the Khan - "the proud ruler" ("Что движет гордою душою? / Какою мыслью занят он?..") ("What moves a proud soul? / What thought is he engaged in?.."). The Tatar translator follows the author, but makes changes; for example, to highlight the authority line in the image of the Khan, he defines his hand as "impressive" ("мәһабәт кулы"), although in the original, the wave of the palm reflects Girey's irritability. Note that the translation of S. Umetbayev does not contain an epigraph from "Bustan" by Saadi, and this was at least strange not only because any non-plot element was part of the idea and design, but also because Saadi was a lyricist, what the translator was aware of; moreover, he could perceive the poem as a response to the themes of Persian literature - the inclusion of a quote from Saadi would raise A. Pushkin in the eyes of Tatar readers additionally, would bring them closer.

N. Isanbet had a different approach. He was in a different cultural and historical context, where the freedom in the painting transfer, if not overcome, is called into question. The principle is to present the descriptions carefully, obscuring oneself as a person with a creative outlook. In the foreground is A. Pushkin and his figurative statement. By this the lack of paired rhyming was dictated in accordance with the copyright, even if not full (ABABCDDCEEF - in the original, ABABCDCDEEF - in the translation). Hence, each translation line is the same value as the origi- nal line. Here, further, and the accuracy of word usage: "раболепный” - "кол дай бамын игән” (fawning, servile), “.. все читали / Приметь гнева и печали” - “Ачу, кайгы эзен алар бар да /

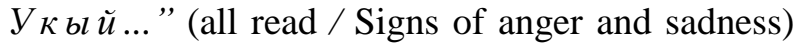
(signs on the face are read in the way the meanings of the book are understood), "Махнул рукой" "Кульнн гына селтәп жсибәрде” (Hе waved), “... идут вон” - “Бар да... ты иика mо $m m$ bl юл" (And all, bowing, go out) (the italics are mine. $-R$. B.). Such accuracy does not cancel out free readings or incorrect ones - in nuances! - interpretations. On the contrary, they are assumed - either in a dosed form, or in the order of elementary randomness (and the major masters have it). In the original, the "face (of the Khan)" is "gloomy". In the translation, there is a noticeable softening: N. Isanbet's "face" acquires "extinct" features (“сүнган йөзе”, ср. “сүнгән йолдыз”") (literal translation: "a faded face", compare: "an extinct star"), the signs of exhaustion, fatigue, decline of mental and physical strength, which are not found in A. Pushkin's text. Would it be more correct to choose a different, appropriate epithet: "караңгылаган" (the Khan sat immersed in sad, painful thoughts, the life of the world did not attract him and the face was "blacker than night", "blacker than darkness", "the nightmare")? At the same time, it is impossible to call N. Isanbet's choice of the lexeme a big mistake: "twilight" comes when the day goes, there is no light, the sun disappears behind the horizon, goes out, and the night follows. N. Isanbet took A. Pushkin's epithet too bluntly: his darkness is not the onset of darkness, but the disappearance of light. Here, of course, shades are important according to the criterion of coincidence / discrepancy with the original. And yet this is not the case to accuse the translator of misrepresenting the author's word. In general, the text is thoughtfully displayed: A. Pushkin remains equal to himself, despite the fact that he is read in Tatar.

Of all the scenes in "Poltava", it is appropriate to stop at the climax of the poem - the episode of the battle between the Russians and the Swedes and see how the meanings of the original are transformed in the translation by N. Isanbet.

\begin{tabular}{|l|l|}
\hline А. С. Пушкин. “Полтава” & \multicolumn{1}{|l|}{$\begin{array}{l}\text { Перевод Наки Исанбета } \\
(1937)\end{array}$} \\
\hline $\begin{array}{l}\text { 1. И грянул бой, Полтав- } \\
\text { ский бой! }\end{array}$ & $\begin{array}{l}\text { 1. Полтава сугышы } \\
\text { күкрәде! }\end{array}$ \\
2. В огне, под градом & $\begin{array}{l}\text { 2. Утлы яңгыр, ялкын } \\
\text { эчендә, }\end{array}$ \\
\hline
\end{tabular}




\begin{tabular}{|c|c|}
\hline $\begin{array}{l}\text { 3. Стеной живою отра- } \\
\text { женным, } \\
\text { 4. Над падшим строем } \\
\text { свежий строй } \\
\text { 5. Штыки смыкает. Тяж- } \\
\text { кой тучей } \\
\text { 6. Отряды конницы лету- } \\
\text { чей, } \\
\text { 7. Браздами, саблями } \\
\text { 3вуча, } \\
\text { 8. Сшибаясь рубятся с } \\
\text { плеча. } \\
\text { 9. Бросая груды тел на } \\
\text { груду, } \\
\text { 10. Шары чугунные по- } \\
\text { всюду } \\
\text { 11. Меж ними прыгают, } \\
\text { разят, } \\
\text { 12. Прах роют и в крови } \\
\text { шипят. } \\
\text { 13. Швед, русский - ко- } \\
\text { лет, рубит, режет, } \\
\text { 14. Бой барабанный, кли- } \\
\text { ки, скрежет. } \\
\text { 15. Гром пушек, топот, } \\
\text { ржанье, стон, } \\
\text { 16. И смерть, и ад со всех } \\
\text { сторон [Пушкин, 1986, с. } \\
\text { 120]. }\end{array}$ & 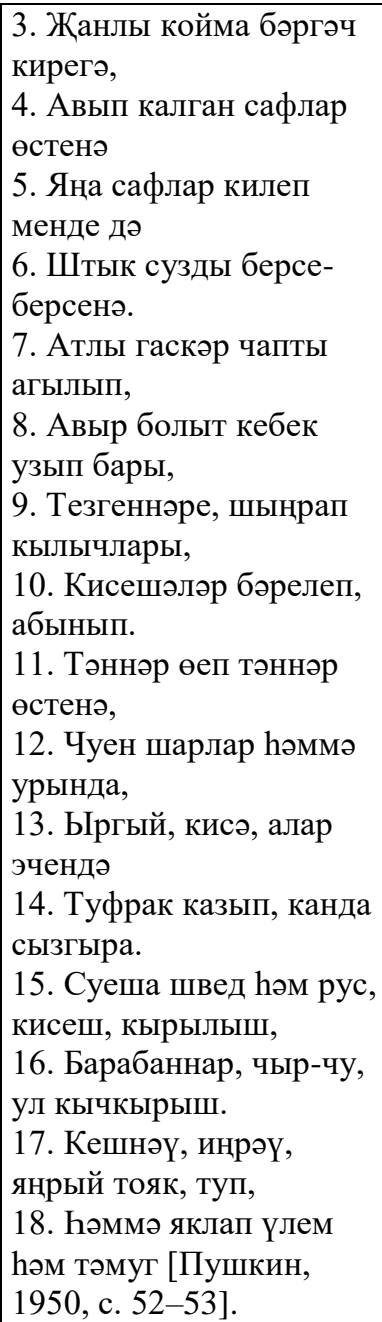 \\
\hline
\end{tabular}

The battle broke out, the battle of Poltava!

In the fire, in a red-hot hail,

Protected by a living wall,

Over a fallen file a new file

Closed its ranks of bayonets. Like a heavy cloud

Detachments of cavalry flew,

Clanking their sabers and bits,

When clashing chopped with a swinging blow.

Throwing a pile of bodies on a pile,

Cast-iron balls were everywhere

Among them hopping, hitting,

Digging ashes and sizzling in the blood.

Swedes, Russians - stabbing, chopping, cutting.

The sound of drums, screams, and gritting,

The thunder of guns and feet, neighing and moaning,

Death and hell on all sides [literal translation].

The battle of A. Pushkin is chaos of nature, a whirl of pain and immeasurable suffering. In the battle, the triumph of the fire element is realized. We see that "cast-iron balls", striking on the sides and swarming deep funnels, come into contact with bodies, so that there is "sizzle in the blood". It is usually red-hot metal that "sizzles" in the forge, when a skilled craftsman plunges it into a cauldron of cold water to cool. But in this particular case, hot cast iron is naturalistically cooled by bloodreplacing water in the world of Russian plain. Depicting the battle-massacre, the poet moves the aesthetic gaze at a faster pace from the subject to the action, in speech expression, he mixes nouns and verbs. A. Pushkin's war is a plastic of bodily confusion, whirlpool, raging feelings, avalanchelike friction. The poet captures the sublime and terrible melody of war, it frightens and delights him.

$\mathrm{N}$. Isanbet hears this subtle ambivalent note, so the focus is not the selection of lexical units, but the phonetic design of the lines. The alliterative increase in voiceless sounds helps to picture the increasing confrontation ([к], [h]): "кисешләр" (are cut), “канда" (in blood), “ㄸaзыл”" (digging), "кешнәY” (neighing), "hәммә" (from all [sides]), "h̆дм" (and), vibrating sounds ([p]): "aвblp" (heavy [cloud]), "тәннәр" (bodies), "виргый" (juтр), “барабаннар” (drums), “яңрый” (trampling sounds), sibilant consonants ([ш], [ч]): "щиарлар" (balls), “кисеще" (chopping), "кырылльщи” (mor), “кычкырыци” (scream),

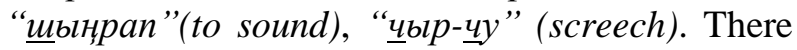
is a number of lines mismatch (two more in translation), but it is compensated by a rhythmicintonation moment that sounds organically - and this is the main thing - in the Tatar language, the preservation of poetic moves ("Aвыn калган сафлар өстенә / Яна сафлар килеп менде дә / Штык сузды берсе-берсенə”), lexical and semantic repetitions (“... сафлар өстенә / Яна сафлар...”, “Тәннәр өеп тәннәр өстенә”), making the episode expressive and eloquent.

Summing up we can say that N. Isanbet developed a special translation style. The components of his style are: a) the accuracy of the original meaning transfer, b) the compliance of the new copy with the norms of the native language, c) deep and comprehensive knowledge of other people's realities displayed in the work, both territorialgeographical and historical-social. In general, if we keep in mind the Soviet school of literary translation, this approach is not new: N. Isanbet lived in his own time, which could not but influence his translation views. However, on the Tatar soil, his method produced significant results, today they must be philologically understood by new translators, to save them wandering in the dark of wrong experimentations, to help them clearly see the highest standard of skill that $\mathrm{N}$. Isanbet (and along with him, other translators, his outstanding con- 
temporaries) created with hard, painstaking work, and to be guided, like a beacon, by it.

The topic "Naki Isanbet as a translator" requires further special-systemic research, which will be actively continued.

\section{References}

Avrutina, A. S., Khabutdinova, M. M. (2018). Nazym Khikmet i tatarskaia kul'tura [Nazym Hikmet and Tatar Culture]. Tatarica. No. 2, pp. 61-77. (In Russian)

Bekmetov, R. F., Spirchagova, T. A. (2017). Tragediia Shekspira "Gamlet" v russkom i tatarskom perevodakh: M. Lozinskii $i$ N. Isanbet [W. Shakespeare's Tragedy "Hamlet" in Russian and Tatar Translations: M. Lozinsky and N. Isanbet]. Filologiia i kul'tura. Philology and culture. No. 2 (48), pp. 133-138. (In Russian)

Dzhambul Dzhabaev: prikliuchenie kazakhskogo akyna v sovetskoi strane (2013) [Dzhambul Dzhabaev: The Adventure of the Kazakh Akyn in the Soviet Country]. 308 p. Moscow, Novoe lite-raturnoe obozrenie. (In Russian)

Frederik, M. (2011). Gabdulla Tukai kak ob"ekt ideologicheskoi bor'by [Gabdulla Tukai as an Object of Ideological Struggle]. Per. s nem. I. A. Giliazova. 343 p. Kazan', Tatarskoe knizhnoe izdatel'stvo. (In Russian)

Galiullin T. N., Khabutdinova M. M. (2014). Zapadnoevropeiskaia klassika $v$ perelozheniiakh $G$. Tukaia [Western European Classics in G. Tukay's Woks]. Tatarica. No. 1(2), pp. 49-61. (In Russian)

Gilazov, T. Sh. (2010). Transformatsiia vzgliadov na tvorchestvo G. Tukaia v 1920-1930-kh godakh [Transformation of Views on G. Tukay's Work in the 1920s and 1930s]. Vestnik Chelyabinskogo gosudarstvennogo universmteta. Filologiia. Iskusstvovedeniie. Vypusk 43. No. 13, pp. 19-25. (In Russian)

Gilazov, T. Sh. (2013). Problema literaturnoi reputatsii G. Tukaia v nauchno-kriticheskoi mysli pervoi chetverti XX veka [The Problem of G. Tukay's Literary Reputation in the Scientific and Critical Thought of the Early Twentieth Century]. Filologiia i kul'tura. Philology and Culture. No. 3 (33), pp. 181-185. (In Russian)

Griboedov, A. S. (1945). Akyllylyk balase / kyskartyp tarææcema ituche Naki Isanbat [Woe from Wit]. Translated by Naki Isanbet. Sovet ədəbiiaty. No. 1, pp. 14-22. (In Tatar)

Griboedov, A. S. (1946). Akyllylyk balase [Woe from Wit]. Nəki Isənbət tərжeməse. 118 p. Kazan, Tatgosizdat. (In Tatar)

Ibragimov, G. G. (2019). Тәræ⿻ета həm апуң shartlary [Translation and Its Conditions. Works: in 15 Volumes]. Osərlər: 15 tomda: 6 t.: Әdəbiyat həm səngat' turynda məkalələr, hezmətlər (1910-1914) (tez., tekst., isk. həm аңl. əzerl. Z. G. Mөhəmmətshin; keresh sYz avt. D. F. Zahidullina). Akademik basma. Pp. 55-57. Kazan, Tatar.kit.nashr.(In Tatar)

Ibragimov, G. G. (2019). Үаң̧а әsərlər, уаң̧а imzalar va yash' kuatlar [New Works, New Signatures, and Young Powers. Works: in 15 Volumes]. Đsərlər: 15 tomda: 7 t.: Odəbiyat həm səngat' turynda məkalələr, hezmətlər (1915-1916) (tez. G. M. Hannanova, Z. G. Mөhəmmətshin; tekst., isk. həm aңl. əzerl. Z. G. Mehəmmətshin; kushymta həm isem. kүrsət. əzerl. G. M. Hannanova; keresh syz avt. D. F. Zahidullina). Akademik basma. Pp. 61-70. Kazan, Tatar.kit.nashr.( In Tatar)

Pushkin, A. S. (1937). Bakchasarai fontany [The Fountain of Bakhchisaray]. Nəki Isənbət tərжeməse. Sovet ədəbiiaty. No. 1, pp. 27-41. (In Tatar)

Pushkin, A. S. (1937). Bakchasarai fontany [The Fountain of Bakhchisaray]. Nəki Isənbət tərжeməse. 40 p. Kazan, Tatgosizdat. (In Tatar)

Pushkin, A. S. (1901). Bakhchasarai fontany [The Fountain of Bakhchisaray]. Metərжеmə: M.-S. Ometbaev. 16 p. Kazan', Tipografiia B. L. Dombrovskogo. (In Arabic)

Pushkin, A. S. (1937). Poltava [Poltava]. Nəki Isənbət tərжeməse. 71 p. Kazan, Tatgosizdat. (In Tatar)

Pushkin, A. S. (1950). Poltava. Bakchasarai fontany [Poltava. The Fountain of Bakhchisaray]. Nəki Isənbət tərжeməse, 82 p. Kazan, Tatgosizdat. (In Tatar) Pushkin, A. S. (1986). Sochineniia: v 3 tomakh. T.

II: Poemy. Evgenii Onegin. Dramaticheskie proizvedeniia [Works: In Three Volumes. Vol. II: Poems. Eugene Onegin. Dramatic Works]. 527 p. Moscow, Khudozhestvennaia literature. (In Russian)

Pushkin, A. S. (1949). Tash kunak [The Stone Guest]. Nəki Isənbət tərжeməse. A. S. Pushkin. Sailanma əsərlər. Pp. 634-667. Kazan, Tatgosizdat. (In Tatar)

Pushkin, A. S. (1954). Tash kunak [The Stone Guest]. Nəki Isənbət tərжеməse. A. S. Pushkin. Sailanma əsərlər 2 tomda. Pp. 672-703. Kazan, Tatgosizdat. (In Tatar)

Pushkin, A. S. (1937). Tash kunak [The Stone Guest]. Nəki Isənbət tərжeməse. 51 p. Kazan, Tatgosizdat. (In Tatar)

Sayfullina, F. S., Valeieva, A. Z. (2017). Fatikh Kutlu kak perevodchik $i$ propagandist tatarskoi literatury $v$ Turtsii [Fatih Kutlu: A Translator and Advocate of Tatar Literature in Turkey]. Tatarica. No. 2(9), pp. 42-64. (In Russian)

Odiplarebez: biobibliografik beleshmalek: 2 tomda (2009) [Literary Biobibliographic Reference Book: In Two Volumes]. T. I: A - K, tez. R. Dautov həm R. Rakhmani. 751 p. Kazan, Tatarstan kitap nəshriiaty. (In Tatar)

Ometbaev, M.-S. (2011). Iəakər: shizyrз̧ar, publitsistik, tarikhi etnografik iaз̧malar, təræ⿻肀一məlar, khalyк iжcady өlgeləre [Memorabilia: Poetry, Journalistic, Historical, Ethnographic Inscriptions, Translations, Samples of Folk Art]. 344 p. Ofe, Kitap. (In Tatar) 


\title{
НӘКЫЙ ИСӘНБӘТ РУС КЛАССИК ӘДӘБИЯТЫН ТӘРЖЕМӘ ИТУЧЕ БУЛАРАК
}

\author{
Ринат Ферганә улы Бекметов, \\ Казан федераль университеты, \\ Россия, 420008, Казан ш., Кремль ур., 18 нче йорт, \\ bekmetov@list.ru.
}

\begin{abstract}
Мәкаләдә Нәкый Исәнбәтнең тәржемә эшчәнлеге тикшерелә. Аның рус классик әдәбиятыннан тәржемәләре, аерым алганда А. С. Пушкинның «Бакчасарай фонтаны» hәм «Полтава» әсәрләренең аерым фрагментлары анализ материалы булып тора. Рус классикасына мөрәжәгать итүнең мәдәни-идеологик контексты, элгәргеләр белән чагыштырганда техник яңалыклары, шулай ук сүз остасының тәржемә принциплары кебек мәсьәләләргә игътибар юнәлтелде. Төп нөсхә мәгънәсенең төгәллеге, яңа, тәржемә текстының туган (татар) телнең нормаларына, аның эстетик алымнарына туры килүе, рус сүз сәнгатенең тасвирланган дөньясына тирәнрәк үтеп керү тәржемәче Нәкый Исәнбәт стиленең мөһим элементларыннан санала. Киләчәктә теманы өйрәнүне, һичшиксез, дәвам итү сорала.
\end{abstract}

Төп төшенчәләр: Нәкый Исәнбәт, рус әдәбияты, татар теле, әдәби тәржемә, чагыштыру hәм тиңләштеру, мәгънәви үзгәрешләр.

Нәкый Исәнбәтнең киңкырлы ижат мирасында әдәби тәржемәләр үзенчәлекле урын алып тора. Язучы эшчәнлегенең бу ягы хакында яхшы билгеле булса да, бүгенге көнгә кадәр ул системалылыктан ерак булган очраклы төстә генә гыйльми-филологик күзалланган: Н. Исәнбәтнең теге яки бу чор тәржемәсен гади фактографик аспектта гына билгеләп үтү аз, ә туган тел чаралары белән чит мәдәният образын тудырганда, ул таянган сәнгати стратегияне, ул эшләгән социальтарихи контекстны, тәржемәнең сайлану принципларын һәм, ниһаять, автор яңалыгының ничек чагылышын ачыклау мөһим. Күләмле булмаган бер мәкалә чикләрендә генә бу проблемаларны иңләп алу мөмкин түгеллеге аңлашыла.

Татар тәржемәчелеге тарихында Н. Исәнбәт - үзенчәлекле фигура һәм маяк, бер этап. Сүз уңаеннан, аны киләчәктә язу кирәклеген ассызыкларга кирәк. Дөрес, татар әдәбият белемендә тәржемә, аның тарихы, принциплары hәм төрләре мәсьәләләренә күпсанлы хезмәтләр һәм мәкаләләр багышланган ([Аврутина, Хабутдинова], [Галиуллин, Хабутдинова, 2014], [Нагуманова, 2017], [Сайфулина, Валеева, 2017] h.б. лар). Н. Исәнбәттә тәржемәчелек темасын бөтенлекле, тулы канлы өйрәнү өчен, авторның тәржемәче ниятенең үсешен детальләрдә күзәтү (аңлы рәвештә булмаса да, ул һәрвакыт яши. P.Б.), аның оригиналны конкрет лексик- семантик hәм коммуникатив-синтаксик чишелештә эшкәртү техникасын ачыклау, чит тел язучыларын язучы тәржемә итә башлаган чорны да истә тотып, Идел-Урал буе татарларында тәржемә эшчәнлеге торышына гомуми күзәтү ясау мөмкинлеге биргән кулъязма фондыннан башлап төрле чыганакларына кадәр өйрәнергә кирәк булыр иде. Рус сурәтле-әдәби сүзнең мәгънәсен бирү процессында, Н. Исәнбәт файдаланган төп юлларны өйрәнү безнең тыйнак максатыбыз булып тора.

Гомумән алганда, Н. Исәнбәт дөнья - рус сүз сәнгатенең генә түгел, ә көнбатыш, көнчыгыш - әдәбиятының гүзәл әсәрләрен тәржемә итү белән шөгыльләнә. Татар халкының мәдәни күтәрелеш дәвере - XX гасыр башы традицияләре дәвамчысы булган язучы аңлы һәм максатлы рәвештә төп нөсхәгә, оригиналга мөрәжәгать итә. Мәсәлән, кайбер биографик күрсәткечләрдә 1940 елларда Шекспирның «Гамлет»ын тәржемә итү өчен, Н. Исәнбәтнең инглиз телен махсус өйрәнү факты әйтелә [Әдипләребез: биобиблиографик белешмәлек, б. 613]; ул рус тәржемә копиясе аша түгел, ә дөньякүләм танылган драматург hәм аның тарафыннан язылган текст белән тыгыз һәм ышанычлы диалог өчен шартлар барлыкка китеру максатыннан эшләнә ${ }^{1}$

\footnotetext{
${ }^{1}$ Н. Исәнбәт тарафыннан, үз максатын ачык аңлаган həм, күпсанлы «тактик» каршылыкларга карамыйча, намуслы үтәлгән һәм аны, ялган пафоссыз бөек, чын
} 
Ул рус әдәбияты фондыннан XIX гасырның икенче яртысы классикларын нәтижәле тәржемә итә. Бу тәржемәләрнең библиографиясе зур түгел: ул үз эченә ике авторны həм дүрт жыентыкны ала. Түбәндә аның тарафыннан тәржемә ителгән рус язучыларының исемнәре һәм әсәрләре китерелә:

1) А. С. Грибоедов: «Акыллылык бәласе» («Горе от ума») комедиясе [Грибоедов, 1945], [Грибоедов, 1946];

мәгънәсендә «эпик» эшчән итеп характерлаган ул вакытлар өчен һич тә жиңел булмаган юл сайлана. Эш шунда: Н. Исәнбәт дәверендә Советлар Берлегенең рус булмаган милләтләре (татарлар 1939 елдан кирилл алфавитын файдаланалар) дөнья әдәбиятының үрнәкләре белән чит әдәбияттан турыдан-туры түгел, ә «икенче кул» - рус теленә тәржемәләре аша танышырга тиеш дигән караш тарала һәм тиз арада гамәли шәкелдә тормышка ашырыла. Чит тел, гамәли аралашу белән аз бәйләнгән грамматика өйрәнүгә йөз тотып, схоластик формада укытыла, ягъни хәзер инглиз, алман, француз телләренең «совет диалекты» гамәлдә булган дип әйтергә билгеле бер нигез бар. Асылда, табигате белән китаби-язма, ә кулланылыш даирәсе буенча «өй», изоляцияләнгән дәүләт нәтижәсе булган «эчке» чит тел барлыкка китерелә. Әлбәттә, мондый чикләнгән формада телләр начар үзләштереләләр. Рус тәржемә мәктәбе, бәхәссез, лингвистик сәләтләре нәтижәсендә генә түгел, ә яшь вакытта чит илдә булу, башка дөньяны күрү һәм тану уникаль мөмкинлегенә ия булган шагыйрьләр hәм язучылар исеме (мәсәлән, С. Я. Маршак, К. И. Чуковский, яки М. Л. Лозинский) белән барлыкка китерелә. Н. Исәнбәт тә, күп татар совет тәржемәчеләре, Бөек Ватан сугышы елларында язмыш кушуы буенча Европада булган Ш. Мөдәррисне искә алмаганда, андый шартларга ия булмый (XX гасыр башында хәлле сәүдәгәр балалары, шагыйрьләр чит илләрдә булганда, аннан китаплар алып кайтып, аларны өйдә арадашчысыз тәржемә итә торган булалар). Моннан оригиналның мәгънәви ягын дөрес аңлау өчен тәржемәчеләрдән чиктән тыш зур көч таләп ителгәнлеге ачык күренә. М. Максуд француз теленнән «Кола Брюньон»ны тәржемә иткәндә, аерым урыннарны ачыклау өчен, М. Л. Лозинскийга мөрәжәгать итә: алар икесе дә Язучылар берлеге әгъзасы була. «Гамлет» белән эшләгәндә, Н. Исәнбәт аннан ярдәм сорады микән, әлбәттә, без бу хакта төгәл әйтә алмыйбыз. Трагедиянең рус һәм татар вариантларын чагыштыру кайбер аерымлыклар булуын күрсәтә. Тәржемә хакында М. Л. Лозинский карашларын уртаклашкан хәлдә, Н. Исәнбәт туган татар теленең кагыйдәләре искә алынган үз юлы белән китә (кара: [Бекметов, Спирчагова, 2017]).
2) А.С. Пушкин: «Бакчасарай фонтаны» («Бахчисарайский фонтан»)» [Пушкин. Бакчасарай фонтаны, 1937, № 1], [Пушкин. Бакчасарай фонтаны, 1937] һәм «Полтава» поэмалары [Пушкин. Полтава, 1937], [Пушкин, 1950], «Таш кунак» («Каменный гость») фажигасе [Пушкин. Таш кунак, 1937], [Пушкин, 1949], [Пушкин, 1954].

Пушкинның ике - «Бакчасарай фонтаны», «Таш кунак» поэмаларының тәржемәләрен кыскача шәрехлик. А. С. Пушкин һәм А. С. Грибоедовның драма тәржемәләрендә геройларны hәм предметларны сурәтләүнең бөтенләй башка һәм үзенчәлекле сәхнә логикасы гамәлгә куелу сәбәпле, алар махсус өйрәнүне сорый. Ә аны театр сәнгатен гажәеп дәрәжәдә оста бәяләгән Нәкый Исәнбәт бик яхшы белгән һәм бу алымнардан файдаланган; без аларны биредә анализламыйбыз.

A. C. Пушкинның атаклы поэмаларына күчик.

Аларның татар теленә тәржемә ителү фактында төп ике шарт- социаль заказ һәм эчке әдәби ситуация - хәлиткеч роль уйный.

Чыннан да, 1937 елда Советлар Берлегендә А. С. Пушкин үлеменең 100 еллыгы зурлап, киң колач белән билгеләп үтелә. Сталин миф тудыру дәверенең hәр тормыш күренешендәге идеологик элемент, төсмер белән бу вакыйга да характерлана. А. С. Пушкин, гәрчә шагыйрь мифы, аеруча рус сүз сәнгатенең «сикерешле», «тизләтелгән» үсешендә А. С. Пушкинның бары тик көнбатыш мәдәни жирлегендә генә гаять зур күренеш буларак барлыкка килү мөмкинлеген hәм аның әһәмиятен объектив шәрехләүне таләп итсә дә, классик йөзьеллык күгендә бердәнбер шагыйрь буларак таныла (ә пролетариат мәдәниятендә В. В. Маяковский шушы рольне уйный $)^{2}$.

Эстетик процессның күренекле, талантлы бер фигурасын аерып алып, аны халыкның өметләрен (идеалларын, ышанычларын. - Р. Б.) чагылдыручы сыйфатында тану гомумсовет тенденциясе, ул вакыт өчен табигый күренеш була. Бу кагыйдә рус әдәбиятына гына түгел, СССР халыкларының милли сүз сәнгатьләренә

\footnotetext{
2 Бу - рус классикасының берьяклы идеяләр һәм стиль монологизмыннан азат булган күп векторлы, күп вариантлы табигатен күрсәтә. Оригинал лирикасы XX гасыр башында зур яңгыраш алып югары бәяләнгән һәм шул чорның мәкаләләрендә символизм хәбәрчесе, «Россия Гетесе» буларак характерланган Ф. И. Тютчев масштаблыгы белән А. С. Пушкин белән бер рәткә куела алмыймыни?
} 
дә карый: украин әдәбиятында Тарас Шевченко пропагандаланган hәм ижтимагый якланган гомуммәхәббәт культына ия була, казах сүз сәнгатендә - Абай (Ибраһим) Кунанбаев һәм Жамбыл Жабаев, татарда - Габдулла Тукай [Фридерих], [Гилазов, 2010], [Гилазов, 2013], (сугыштан соңгы елларда - Муса Жәлил), төрекмәндә - Мәхтүмкули: бу исемлекне тагын да дәвам итәргә булыр иде... Алар популяр һәм академик серияләрдә хәзерге вакыт үлчәмнәрендә акылга сыймаслык чиксез зур тиражларда нәшер ителәләр, дөнья телләренә тәржемә ителәләр (Н. Исәнбәтнең дә А. С. Пушкиннан тәржемәләре нәкъ менә 1937 елда басыла. - P. Б.) алар хакында шәхси, аерым мәкаләләр һәи коллектив монографияләр языла - кыскасы көчле идеологик машина, материаль hәм финанс чыгымнары белән исәпләшмичә, «сакраль», изге мәгънәләр житештерүче фабрика барлыкка китерә, ә монда тәржемәчеләр иң якыннан катнашалар. Моннан шулай ук Н. Исәнбәт тә чыгарма түгел ${ }^{3}$.

3 Шуны ачыкларга кирәк: тәржемә ителгән язучылар, бәхәссез, мактауга лаеклы иделәр. А.С.Пушкин - «рус поэзиясенең кояшы» гыйбарәсе белән кем бәхәсләшер? Мәсьәлә менә нәрсә дә, халыкчан килеп чыгышы я булмаса гади халыкка теләктәшлеге сыйфаты буенча бер шәхесне алгы планга чыгарып, совет идеологиясе тарихы берничә гасырларга сузылган мәдәниятләрне артык гадиләштерә. Г. Тукай бөек, әмма татар әдәбияты аннан башка элитар, хәрәкәт векторының рухы белән аристократ, әмма «милли-буржуаз элементлар», ягъни «социаль яктан чит» катлавына кертелгән Дәрдемәндкә дә ия була. Муса Жәлил Советлар герое пантеонына кертелү сәбәпле, аның ижаты үтә уңай бәя ала. Тирән анализга дәгъва итмичә, шагыйрьнең башлангыч чор әсәрләре белән танышу аларның сәнгати яктан үлем тырнагында рухи киеренкелек hәм ихтыяри тырышлык жимешләре «Моабит дәфтәрләре» белән чагыштырганда камил түгеллеген раслый. Совет властеның, Жамбул белән булган кебек, шагыйрьне көнүзәгендәге ижтимагый мәсьәләләргә юнәлтелгән тематик линиядә ясалма үстерү омтылышы (бу дала акыны тарафыннан язылганнарның күбесе, авторлык хокукы буенча аңа карамый; текстларның күпчелеген әүвәл гадәти казах мөнәжәтләре, шигъри әсәрләре стилендә урта кул рус шагыйрьләре яза, ә яңадан алар Жамбул тарафыннан аның якын даирәсендәге кешеләрнең кыска сөйләп бирүләре hәм ачыклаулары нигезндә туган телгә күчерелә, болар бөтенесе казах теленнән тәржемә итеп тәкъдим ителәләр [Джамбул Джабаев]), алар конкрет сыйфат, үзенчәлекләр хакында сораулар тудырмыйча калдырмый.
Мәгълүм булганча, татар халкының ижтимагый-рухи һәм мәдәни янарышы чорында аерым газеталар-журналлар редакциясендә тәржемәчеләр клубы оештырыла, «тәржемәчеләрнең яңа буыны формалаша: С. Рахманколый, И. Богданов. В. Әхмәдуллин, Г. Кәрам, В. Апанаев, И.Казаков. Алар белән янәшә Г. Тукай, Ф. Әмирхан, Г. Камал, С. Рәмиев, Г. Исхакый, Г. Рәхимнәр бу эшкә актив катнашып китәләр» [Нагуманова, с. 73]. Тәржемә әсәрләренең саны көннән-көн арту, аңа ихтыяж үсү татар галимнәренең, тәнкыйтьчеләренең тәржемәнең теоретик нигезләре, төрләре, принциплары һәм ысуллары хакында уйланырга, барлыкка килгән тәжрибәне өйрәнүгә һәм нәзари гомумиләштерүгә этәрә. Мәсәлән, Г. Тукайның бу тармакта аеруча осталыгы, тәржемә эшен әдәби ижат дәрәжәсенә күтәрүе югары бәяләнә [Галиуллин, Хабутдинова, с. 56-57].

XX гасыр беренче утызеллыгы татар мәдәнияте hәм әдәбиятының күренекле язучысы, әдәбият галиме Г. Ибраһимов «татар халкының психологиясенә вә тәрәккыяте фикриясенә мөнасиб булырлык (фикер үсешенә туры килерлек), аларның бер ярасына шифа бирерлек вә бер ихтыяжларын капларлык булган бер әсәрне сайлау») [Ибраһимов, 6 т., 2019, б. 56] принцибын мөһим дип саный. Галимнәр, ижат кешеләре С. Сүнчәләйнең А. С. Пушкиннан «Вәхи», Байроннан «Тоткын», Г. Гейнедан «Әлмансур»ны тәржемә итеп, Шәрык һәм Гаребнең күренекле язучыларының әдәби хәзинәләреннән бу көнгәчә мәхрүм булган татарларны таныштыруын югары бәяли [Ибраһимов, 7 т., 2019], [Казанлы]. Әмма шагыйрьнең күп әсәрләрне, аеруча «Әлмансур»ны миллиләштерәм дип, асылын үзгәртүе гафу ителмәслек «әдәби жинаять» төсендә тискәре мөнәсәбәт ала [Ибраһимов, 7 т., 2019, б. 67]. Күренә ки, 1910 еллар гыйльмитәнкыйди фикере тарафыннан тәржемәчеләргә, әдәби эшчәнлекнең бу төренә югары таләпләр куелган. Шул рәвешле Ауропа-рус язучыларына мөнәсәбәт формалаша, алар әсәрләренең идея-эстетик кыйммәте кыйммәте билгеләнә.

Татар укымышлылары даирәсендә XIX ахыры - XX гасыр башында беренче танышудан башлап гений А.C. Пушкинга мөнәсәбәт аеруча зур жаваплылык, сак караш белән характерлана. Иң беренче нәүбәттә, А. С. Пушиннан тәржемәләре, аның әсәрләренең ирекле күчерелүләре, икътибаслары белән 
тәкъдир ителгән үзенчәлекле татар пушкинианасы яши; яңа ысул мәктәпләренә кертелә башлаган жәдитчелек күрсәтмәләренә (рус теле югары белем бирү теле итеп таныла, шуның аркасында фәнгә, сәнгать өлкәсенә һәм дәүләт тормышына ишек ачыла. - $P$. Б.) мантыйкый нигезләнгән жавап төсендә рус классикасының иң югары дәрәжәсе дип танылган культ урнаша.

Әлбәттә, тәржемәгә бөтен әсәрләр дә түгел, ә сурәтләнгән мәдәни-географик һәм дини реалийлары якын булган ижат жимешләре генә алына.

Шулай М. Ю. Лермонтовның, роман бөтенлеген жимереп һәм «Безнең заман герое» («Герой нашего времени») составындагы повестьларга игътибар итмичә, «Ашик-Кериб» (Ашик - Гариб / Ашуг - Гариб) төрек әкиятен, яисә «Бэла»сын тәржемә итү артыграк күрелә: рус язучысы тарафыннан теләктәшлек белән сурәтләнеп, хатын-кызлар язмышы хакында сентименталь уйланулар белән бер яссылыкта булган яшь тәжрибәсез кыз язмышы кызыксыну уятмыйча кала алмый (H. М. Карамзин «Бичара кызы»ның («Бедная Лиза»), персонажлар исемен, сюжет барышын һәм шартларны, туган, күнегелгән реальлеккә жайлаштыру нияте белән татарчалаштырып, ирекле рәвештә үзгәртеп тәржемә ителүе игътибарга лаек. - Р.Б.); Л. Н. Толстойдан теләсә нинди властька әхлакый тәэсирлелеккә буялган горур каршылыгы белән «Хажи Мурат»ы («Хаджи Мурат») кавказ повесте татарчалаштырыла. Аларны күп тапкырлар тәржемә итәләр, ә бәясе зур булмаган китаприсаләләр тиз арада сатылып бетә. Н. Исәнбәт, әлбәттә, бөтен татарлар яраткан А. С. Пушкинны тәржемә иткәндә, элгәргеләр тәжрибәсен искә алган.

Ул «Полтава»ны, күрәсең, мөхәррир сайлавы белән заказ буенча тәржемә иткән: беренчедән, 1930 еларда урнашкан идеологик монизм рус тарихының монументаль шәрехләнүенә ярдәм итә, аны СССРның рус булмаган халыкларына тапшырырга кирәк була; икенчедән, Язучылар берлегенең милли бүлекләре планына бөек шагыйрьне кин масштабта таныту бурычы кертелә, ә ул, Ү3 чиратында, А. С. Пушкинның татарчага тәржемә ителмәгән әсәрләрен нәшер итүне көн тәртибенә куя. «Бакчасарай фонтаны»на («Бахчисарайский фонтан») килгәндә, Н. Исәнбәткә кадәр бу көньяк поэмасын тәржемә итәләр, башкача була да алмый - биредә Идел буе татарларының тарихи тамырлары белән, Алтын Урда таркалып, Казан ханлыгы оеша башлау чорына һәм Гәрәй династиясе вәкилләренең Казан тәхетендә (кырым партиясе. $-P$. Б.) идарә итүләренең иң югары ноктасы вакытына барып тоташкан Кырым сурәтләү объекты булып тора.

1899-1900 елларда А. С. Пушкин поэмасын Мөхәммәд-Сәлим Өметбаев тәржемә итә, һәм, әлбәттә, ул тикшерелеп, Санкт-Петербуг цензурасының 1900 елның 27 ноябре белән даталанган махсус рөхсәте бирелгәннән соң, Казанда Б. Л. Домбровскийнең шәхси матбагасында дөнья күрә [Пушкин, 1901] $]^{4}$.

Хәзер «Бакчасарай фонтан»ының ике тәржемәсеннән сайлап алынган өзекләрне чагыштырып карау максатка ярашлы булыр. Пушкин поэмасының куәтле дәүләтнең башлыгы Гәрәй тасвирланган өзеген башламын алыйк.

\begin{tabular}{|c|c|c|}
\hline $\begin{array}{c}\text { А.С. Пушкин. } \\
\text { «Бахчасарай } \\
\text { фонтаны» }\end{array}$ & $\begin{array}{c}\text { Сәлим Өметбаев } \\
\text { тәржемәсе } \\
\text { («Бахчасарай } \\
\text { фонтаны», 1900) }\end{array}$ & $\begin{array}{c}\text { Нәкый Исәнбәт } \\
\text { тәржемәсе } \\
\text { («Бакчасарай } \\
\text { фонтаны», 1937) }\end{array}$ \\
\hline $\begin{array}{l}\text { 1. Гирей сидел, } \\
\text { потупя взор; } \\
\text { 2. Янтарь в } \\
\text { устах его } \\
\text { дымился; } \\
\text { 3. Безмолвно } \\
\text { раболепный } \\
\text { двор } \\
\text { 4. Вкруг хана } \\
\text { грозного } \\
\text { теснился. } \\
\text { 5. Все было } \\
\text { тихо во дворце; } \\
\text { 6. Благоговея, } \\
\text { все читали } \\
\text { 7. Приметы }\end{array}$ & $\begin{array}{l}\text { 1. Утырып } \\
\text { (утыра) } \\
\text { Бахчасарайда, / } \\
\text { Түбән карап } \\
\text { Гәрәй хан. } \\
\text { 2. Авыздагы } \\
\text { янтарьдан / } \\
\text { Уйнатадыр иде } \\
\text { дәхан (төтен); } \\
\text { 3. Яранлары } \\
\text { (иптәшләре, } \\
\text { дуслары) тып- } \\
\text { тыныч / Чура } \\
\text { янларын ләмыш } \\
\text { (түгәрәкләп } \\
\text { урын алганнар), }\end{array}$ & $\begin{array}{l}\text { 1. Гәрәй утыра } \\
\text { иде карап түбән, } \\
\text { 2. Хур-хур төти } \\
\text { иде авызында; } \\
\text { 3. Якыннары } \\
\text { колдай башын } \\
\text { игән, } \\
\text { 4. Сыенып } \\
\text { дәһшәтле хан } \\
\text { алдында. } \\
\text { 5. Бар да тып- } \\
\text { тын иде бу } \\
\text { сарайда; } \\
\text { 6. Зурлап аны } \\
\text { ихлас күнелдән, } \\
\text { 7. Ачу, кайгы }\end{array}$ \\
\hline
\end{tabular}

4 Өметбаев Мөхәммәд-Сәлим Ишмөхәммәт улы (1881-1907) күренекле башкорт мәгърифәтчесе, шагыйрь, тәржемәче, филолог, этнограф, жәмәгать эшлеклесе, Рус географик жәмгыятенең Оренбург бүлеге hәм А. С. Пушкин тууының 100 еллык юбилеен бәйрәм итү комиссиясенең әгъзасы, моннан тыш вакыф эшләре (Исламда. - милеккә бәйләнгән. - P. Б.) Россия Эчке эшләр министрлыгының Кырым комиссиясе составына кергән. Аның турында һәм фәнни-әдәби ижаты хакында кара: [Өмөтбаев, б. 5-62]. Басма поэманың тышында тәржемәченең фамилиясе һәм исеме алдыннан, маркировкалаучы рәтнең берәмлеге буларак «башкорт» сүзе куелган (чагыштыр: «мөтәржемә: башкорт Мөхәммәдсәлим Өмөтбаев»). 


\begin{tabular}{|c|c|c|}
\hline $\begin{array}{l}\text { гнева и печали } \\
8 . \text { На сумрачном } \\
\text { его лице. } \\
9 . \text { Но } \\
\text { повелитель } \\
\text { горделивый } \\
\text { 10. Махнул } \\
\text { рукой } \\
\text { нетерпеливой: } \\
\text { 11. И все, } \\
\text { склонившись, } \\
\text { идут вон } \\
\text { [Пушкин, 1986: } \\
\text { с. 48]. }\end{array}$ & $\begin{array}{l}\text { 4. Гәрчә сарай } \\
\text { фәрагать } \\
\text { (тынлык, ял), / } \\
\text { Ханның йөзе } \\
\text { саргаймыш. } \\
5 . \text { Кылды Гәрәй } \\
\text { мәһабәт / Кулы } \\
\text { илә (белән) } \\
\text { ишарәт, } \\
\text { 6. Халкы } \\
\text { тышка(ры) (ук) } \\
\text { чыгып, / Кылды } \\
\text { (буйсынып } \\
\text { хөрмәт). } \\
\text { 7. Ялгыз калып } \\
\text { сарайда, / Шәп } \\
\text { тын ала күкрәге, } \\
8 . \text { Газаплы баш } \\
\text { тулкының, / } \\
\text { Басыр им(н)де } \\
\text { йөрәге. } \\
\text { 9. Болыт та } \\
\text { шулай беленер, / } \\
\text { Яннарында } \\
\text { күренер, } \\
10 . \text { Пыялага } \\
\text { кыелса, / Гаксе } \\
\text { беленер рәңле } \\
\text { (төрле төстәге) } \\
\text { нур, } \\
11 . \text { Горурлыкмы } \\
\text { ханыңа? / Төште } \\
\text { сәуда (уй-теләк) } \\
\text { жанына } \\
\text { [Пушкин, 1901: } \\
\text { 2], кара.: } \\
\text { [Өмөтбаев. } \\
\text { 2011: б. 170]. }\end{array}$ & $\begin{array}{l}\text { эзен алар бар да } \\
\text { 8. Укый аның } \\
\text { сүнгән } \\
\text { йөзеннән. } \\
\text { 9. Ләкин } \\
\text { мәгърур хаким } \\
\text { түзмәде, } \\
\text { 10. Кулын гына } \\
\text { селтәп жибәрде, } \\
\text { 11. Бар да иелеп } \\
\text { тышка тотты юл } \\
\text { [Пушкин, 1950: } \\
\text { б. 63]. }\end{array}$ \\
\hline
\end{tabular}

С. Өметбаевның төрки телгә тәржемәсе классик төрки-татар (киңрәк - шәркый. - Р.Б.) поэтиканың шигырь төзелешенә яраклаштырылган. Мисраглар яртыюллыкларга бүленгән, ритмикада жиңеллекне тәэмин итү өчен, мисрагларда, шул исәптән яртыюллыклар эчендә дә парлы рифма еш кулланыла. Текст стиле күренешне аңлатуга йөз тота (оригинал чикләре бозылганда: мәсәлән, оригиналның 11 юлы - тәржемәдә бу 6 юл. - Р.Б.). А. С. Пушкин әсәрендә романтик сер бар: шагыйрь сарайда Гәрәй дулкынлануы хасил иткән тынлык сурәтен тудыра. Әлеге өзектә бу халәтнең сәбәбе турында әйтелми: автор хикәяләүне сер пәрдәсенә, томанына төрә; өченче строфада ул риторик сораулар кую аша «горур падишаһ» - хан «караңзгылысг»ының сәбәпләре хакында укучыны уйланырга (аның белән бер үк хокукларда үзе дә уйлана. - Р.Б.) мәжбүр итә: («Горур ж⿻анны нәрсә хәрәкәт иттерә? Нинди уй белән ул мәшгуль») [(«Что движет гордою душою? / Какою мыслью занят он?..»)] (сүзгә-сүз тәрж. - P. Б.). Татар тәржемәчесе үзгәрешләр кертеп, автор артыннан бара: әйтик, хан образында хакимлек итәргә яратучанлыкны көчәйтү өчен, аның кулын, гәрчә уч зурлыгы оригиналда Гәрәйнең ризасызлыгын чагылдырса да, «мәһабәт кул» дип сыйфатлый. С. Өметбаев тәржемәсендә Сәгъдинең «Бустан»ыннан алынган эпиграфның юклыгын билгеләргә кирәк. Бу факт теләсә нинди сюжеттан тыш элементның әсәр идеясе һәм уйланмасының бер өлеше булганга гына түгел, ә Сәгъдинең лириклыгы турында тәржемәченең хәбәрдар булуы ягыннан гажәп; моннан тыш ул поэманы фарсы әдәбияты темасының яңгырашы буларак та кабул итәргә мөмкин иде; Сәгъдидән өзекне кертү татар укучылары алдында А. С. Пушкинның дәрәжәсен күтәрер, аларга якынайтыр иде.

Н. Исәнбәттә алай түгел. Ул, сурәтне бирүдә иреклелеккә ирешмәсә дә, аны шик астына алган мәдәни-тарихи контекстта тора. Принцип бер - үзеңнең киң карашлы ижат шәхесе булуыңны арткы планга калдырып, тасвирны саклык белән аңлату. Беренче урында - А. С. Пушкин, аның образлы фикерләре. Парлы рифманың юклыгы һәм аның тулы булмаса да авторныкына туры килүе (оригиналда - АБАБВГГВДДЖ, тәржемәдә АБАБВГВГДДЖ) шуның белән аңлатыла. Тәржемәнең һәр юлы мәгънәсе белән төп нөсхә мисрагларына аваздаш. Биредә сүзләр куллланылышы да төгәл: «к о л $\partial$ a й башын игән» - «раболепный», «Ачу, кайгы эзен алар бар да / У к ы й...»-«... все читали / Приметы гнева $и$ печали» (хан йөзендәге билгеләр китапның мәгънәсе аңлашылганча укыла), «Кульын гына с е л $m$ ә $n$ ж⿻ и б ә $p$ д е» -

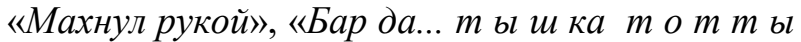
$ю$ л» - «... идут вон» (ассызык. - Р.Б.). Мондый төгәллек ирекле укуны яисә дөрес булмаган шәрехләүләрне - нюансларда! - кире какмый. Киресенчә, алар билгеле бер күләмдә, я булмаса элементар очраклылык тәртибендә (ул күренекле сәнгать осталарында да була. - Р.Б.) күз алдында тотыла. Төп нөсхәдә «(хан) йөзе» (лицо (хана)) - «караңъгыљ» (сумрачное). Тәржемәдә сизелерлек йомшарту күзәтелә: Исәнбәттә «йөз» Пушкинда булмаган көчсезлек, арыганлык, физик һәм рухи төшенкелек билгесе булган «сүнгән» сызыгын 
(«сүнгән йөзе», чагыштыр: «сүнгән йолдыз»)) ала. Туры килгән, башка эпитетны сайлау дөрес булмас иде: «караңгыланган» (хан күңелсез уйларга баткан, тирә-яктагы дөнья инде аны кызыксындырмый, hәм бүгеннән йөзе «төннән дә карарак», «караңгылыктан да карарак», «болыттан да карарак»)? Шул ук вакытта Н. Исәнбәттәге лексемалар сайланышын тупас хата дип санарга ярамый: «ярым караңгылык» (эңгер-меңгер) - көн кичкә авышкан, караңгылык иңгән, кояш горизонт артында батып сүнгән вакыт, һәм төн башлана. $\mathrm{H}$. Исәнбәт А. С. Пушкин эпитетын артык туры кабул иткән: аның караңгылыгы күңелдәге караңгылык түгел, ә яктылык бетү, юкка чыгу. Монда, әлбәттә, оригинал белән тәңгәл килү / тәңгәл килмәү критерийларының төсмерләре мөһим. Бу тәржемәчене автор сүзен бозуда гаепләү өчен ассызыкланган очрак та түгел. Гомумән алганда, текст төптән, тирәнтен уйланып тәржемә ителгән, аны татарча укысалар да, Пушкин үзенә тугры калган.

«Полтава»ның барлык күренешләреннән поэманың кульминацион ноктасы - руслар белән шведлар арасындагы сугыш эпизодларына тукталу һәм Н. Исәнбәт тәржемәсендә төп нөсхәнең мәгънәләре үзгәрешен карау урынлы булыр.

\begin{tabular}{|c|c|}
\hline $\begin{array}{c}\text { А.С. Пушкин. } \\
\text { «Полтава» }\end{array}$ & $\begin{array}{c}\text { Нәкый Исәнбәт } \\
\text { тәржемәсе (1937) }\end{array}$ \\
\hline $\begin{array}{l}\text { 1. И грянул бой, Полтав- } \\
\text { ский бой! } \\
\text { 2. В огне, под градом рас- } \\
\text { каленным, } \\
\text { 3. Стеной живою отра- } \\
\text { женным, } \\
\text { 4. Над падшим строем } \\
\text { свежий строй } \\
\text { 5. Штыки смыкает. Тяж- } \\
\text { кой тучей } \\
\text { 6. Отряды конницы лету- } \\
\text { чей, } \\
\text { 7. Браздами, саблями зву- } \\
\text { ча, } \\
\text { 8. Сшибаясь рубятся с } \\
\text { плеча. } \\
\text { 9. Бросая груды тел на } \\
\text { груду, } \\
\text { 10. Шары чугунные по- } \\
\text { всюду } \\
\text { 11. Меж ними прыгают, } \\
\text { разят, } \\
\text { 12. Прах роют и в крови } \\
\text { шипят. } \\
\text { 13. Швед, русский - ко- }\end{array}$ & $\begin{array}{l}\text { 1. Полтава сугышы } \\
\text { күкрәде! } \\
\text { 2. Утлы яңгыр, ялкын } \\
\text { эчендә, } \\
\text { 3. Жанлы койма бәргәч } \\
\text { кирегә, } \\
\text { 4. Авып калган сафлар } \\
\text { өстенә } \\
\text { 5. Яңа сафлар килеп } \\
\text { менде дә } \\
\text { 6. Штык сузды берсе- } \\
\text { берсенә. } \\
\text { 7. Атлы гаскәр чапты } \\
\text { агылып, } \\
\text { 8. Авыр болыт кебек } \\
\text { узып бары, } \\
\text { 9. Тезгеннәре, шыңрап } \\
\text { кылычлары, } \\
\text { 10. Кисешәләр бәрелеп, } \\
\text { абынып. } \\
\text { 11. Тәннәр өеп тәннәр } \\
\text { өстенә, } \\
\text { 12. Чуен шарлар һәммә } \\
\text { урында, } \\
\text { 13. Ыргый, кисә, алар }\end{array}$ \\
\hline
\end{tabular}

\begin{tabular}{|l|l|}
\hline лет, рубит, режет, & эчендә \\
14. Бой барабанный, кли- & 14. Туфрак казып, канда \\
ки, скрежет. & сызгыра. \\
15. Гром пушек, топот, & 15. Суеша швед hәм рус, \\
ржанье, стон, & кисеш, кырылыш, \\
16. И смерть, и ад со всех & 16. Барабаннар, чыр-чу, \\
сторон [Пушкин, 1986: с. & ул кычкырыш. \\
$120]$. & 17. Кешнәү, иңрәү, \\
& яңрый тояк, туп, \\
& 18. һәммә яклап үлем \\
& hәм тәмуг \\
& [Пушкин, 1950: б. 52- \\
& 53]. \\
\hline
\end{tabular}

А. С. Пушкин өчен сугыш - ул стихияләр хаосы, кайгы-хәсрәтләрнең һәм чиксез газапларның туктаусыз хәрәкәте. Зур сугышларда ут беренчел элементының тантанасы тормышка ашырыла. Без, тирә-якны кырып һәм тирән чокырлар чокып, «канда чыжжылдау» өчен «чуен шарларыныңң» тәнгә тиюн күрәбез. Кагыйдә буенча, тимерче алачыгында кызыл төскә кергәнче кыздырылган металл оста тимерче тарафыннан, суыту нияте белән, салкын суга батырылгач «чыљжлый». Әмма бу конкрет очракта кайнар чуен рус тигезлекләрендә су белән алыштырылган кан белән натуралистларча суына. Шагыйрь сугыш-үтерешне тасвирлап, эстетик игьтибарны тизләтелгән темпта предметтан хәрәкәткә күчерә, ул сөйләмдә исемнәрне фигыльләр белән аралаштыра. Пушкин сугышы - тәннәр катнашмасының, вакыйгалар өермәсенең, хисләр ярсуының, көчләр ташкының пластикасы. Шагыйрь сугышның югары-куркыныч яңгырашын, көен тотып ала, ул аны куркыта да, сокландыра да.

Н. Исәнбәт, бу нечкә, гадәттән тыш нотаны, яңгырашны ишетү сәбәпле, төп игътибарын лексик берәмлекләр сайлауга түгел, ә мисрагларны фонетик формалаштыруга юнәлтә. Каршылыклар көчәя барган сугыш күренешләре белән саңгырау тартыклар кабатлануының артуы идарә итә: (йомык hәм

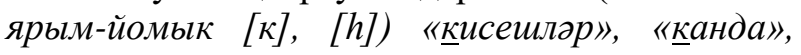

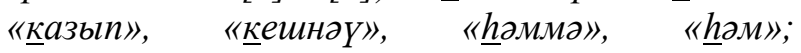

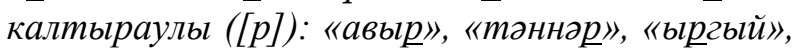
«барабаннар», «янцый»); чыжылдаулы ([ш],

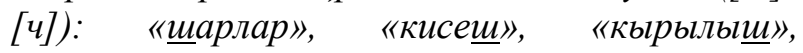

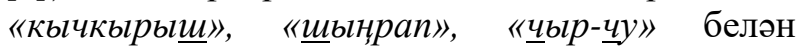
тәэмин ителә. Шигырь юлларының туры килмәве (тәржемә ике мисрагка артыграк. Р.Б.), татар теле өчен мөһим булып, табигый яңгыраган ритмик-интонацион момент, поэтик həм, метрик үлчәм белән интонационсинтаксик бәйләнешләр тәңгәл килмәү 
аркасында, фразаларның бер өлешен икенче юлга күчерүләр (анжамбеманнар. - $P$. Б.) («Авып калган сафлар өстена / Януа сафлар килеп менде дә / Штык сузды берсе-берсенд»), сурәтне тагын да тәэсирлерәк, матуррак итә торган лексик-мәгънәви кабатлаулар белән («... сафлар өстенә / Яйа сафлар...», «Тәннәр өеп тәннәр өстенә») компенсацияләнә.

Күзәтүләргә нәтижә ясап, шуны әйтергә мөмкин: Н. Исәнбәт үзенчәлекле тәржемә формасын эшли. А) төп нөсхәнең мәгьнәсен бирү, б) яңа күчермәнең туган тел кагыйдәләренә туры килүе, в) әсәрдә чагылган территориаль-географик һәм тарихи-социаль пландагы чит реалийларны тирән һәм жентекле белү аның стиленең состав элементлары булып тора.

Гомумән алганда, әгәр дә әдәби тәржемәнең совет мәктәбен күздә тотсак, бу караш яңа түгел. Н. Исәнбәт тәржемәчелек стратегиясенә аның карашларын билгели торган «үз вакытында» яши. Әмма аның ысулы, юлы татар туфрагында кыйммәтле нәтижәләр бирә һәм алар яңа тәржемәчеләрнең, тәжрибәләр ясауның ялгыш аңланган караңгылыгында адашмыйча, Н. Исәнбәтнең (аның белән башка тәржемәчеләр, күренекле замандашлары да була - Р.Б.) авыр, тырыш хезмәте белән барлыкка китерелгән осталыкның югары нормасын ачык күзалласыннар өчен, бүген филологик аспектта аңланылырга тиеш.

«Тәржемәче буларак Нәкый Исәнбәт» темасы киләчәктә махсус-системалы өйрәнүләрне көтә. Бу юнәлештә нәзари эзләнүләр актив дәвам итәр дип ышанасы килә.

\section{Әдәбият}

Әдипләребез: биобиблиографик белешмәлек: 2 томда. Т. I: А - К / төз. Р. Даутов һәм Р. Рахмани. Казан: Татарстан китап нәшрияты, 2009. 751 б.

Грибоедов А. С. Акыллылык бәласе / кыскартып тәржемә итүче Нәкый Исәнбәт // Совет әдәбияты. 1945. № 1. Б. 14-22.

Грибоедов А. С. Акыллылык бәласе / Нәкый Исәнбәт тәржемәсе. Казан: Татгосиздат, 1946. 118 б.

Ибраһимов Г. Г. Тәржемә һәм аның шартлары // Әсәрләр: 15 томда: 6 т.: Әдәбият һәм сәнгать турында мәкаләләр, хезмәтләр (1910-1914) [төз., текст., иск. һәм аңл. әзерл. 3. Г. Мөхәммәтшин; кереш сүз авт. Д. Ф. Заһидуллина]. Академик басма. Казан: Татарстан китап нәшрияты, 2019. Б. 55-57.

Ибраһимов Г. Г. Яңа әсәрләр, яңа имзалар вә яшь куәтләр // Әсәрләр: 15 томда: 7 т.: Әдәбият һәм сәнгать турында мәкаләләр, хезмәтләр (1915-1916) [төз. Г. М. Ханнанова, 3. Г. Мөхәммәтшин; текст., иск. һәм аңл. әзерл. 3. Г. Мөхәммәтшин; кушымта həм исем. күрсәт. әзерл. Г. М. Ханнанова; кереш сүз авт. Д. Ф. Заһидуллина]. Академик басма. Казан: Татарстан китап нәшрияты, 2019. Б. 61-70.

Казанлы Ф-С. Тәржемә бабында тәжрибәләр («Әл-Мансур» мөнәсәбәте белән) // Аң. 1914. № 4. Б. 83-85; № 5. Б. 103-104; № 8. Б. 165-168; № 9. Б. 180-182 .

Нагуманова Э. Ф. Современная татарская поэзия в переводе на татарский язык. Tatarica. 2017. № 1 (8). C. $63-82$.

Өметбаев М.-С. Йәдкәр: шиғырзар, публицистик, тарихи этнографик язुмалар, тәржемәләр, халык ижады өлгөләре. Өфө: Китап, 2011. 344 б.

Пушкин A. С. Бакчасарай фонтаны / Нәкый Исәнбәт тәржемәсе // Совет әдәбияты. 1937. № 1. Б. 27-41.

Пушкин А. С. Бакчасарай фонтаны / Нәкый Исәнбәт тәржемәсе. Казан: Татгосиздат, 1937. 40 б.

Пушкин А. С. Бахчасарай фонтаны / мөтәржемә: М.-С. Өмөтбаев. Казань: Типография Б. Л. Домбровского, 1901. 16 б.

Пушкин A. C. Полтава / Нәкый Исәнбәт тәржемәсе. Казан: Татгосиздат, 1937. 71 б.

Пушкин А. С. Полтава. Бакчасарай фонтаны / Нәкый Исәнбәт тәржемәсе. Казан: Татгосиздат, 1950. 82 б.

Пушкин А. С. Таш кунак / Нәкый Исәнбәт тәржемәсе // А. С. Пушкин Сайланма әсәрләр. Казан: Татгосиздат, 1949. Б. 634-667.

Пушкин А. С. Таш кунак / Нәкый Исәнбәт тәржемәсе // А. С. Пушкин Сайланма әсәрләр 2 томда. Казан: Татгосиздат, 1954. Б. 672-703.

Пушкин A. C. Таш кунак / Нәкый Исәнбәт тәржемәсе. Казан: Татгосиздат, 1937. 51 б.

Аврутина А. С., Хабутдинова М. М. Назым Хикмет и татарская культура // Tatarica. 2018. № 2. C. 61-77.

Бекметов Р. Ф., Спирчагова Т. А. Трагедия Шекспира «Гамлет» в русском и татарском переводах: М. Лозинский и Н. Исанбет // Филология и культура. Philology and culture. 2017. № 2 (48). С. 133-138.

Галиуллин Т. Н., Хабутдинова М. М. Западноевропейская классика в переложениях $\Gamma$. Тукая // Tatarica. 2014. № 1(2). C. 49-61.

Гилазов Т.Ш. Трансформация взглядов на творчество Г. Тукая в 1920-1930-х годах // Вестник Челябинского государственного университета. Филология. Искусствоведение. Выпуск 43. 2010. № 13. C. $19-25$.

Гилазов Т.Ш. Проблема литературной репутации Г. Тукая в научно-критической мысли первой четверти XX века. // Филология и культура. Philology and culture. 2013. № 3(33). C. 181-185.

Джамбул Джабаев: приключение казахского акына в советской стране. М.: Новое литературное обозрение, 2013. 308 с. 
Пушкин А. С. Сочинения: в 3 томах. Т. II: Поэмы. Евгений Онегин. Драматические произведения. М.: Художественная литература, 1986. 527 с.

Сайфулина Ф. С., Валеева А. 3. Фатих Кутлу как переводчик и пропагандист татарской литературы в Турции. Tatarica. 2017. № 2(9). С. 42-64.
Фредерик М. Габдулла Тукай как объект идеологической борьбы / пер. с нем. И. А. Гилязова. Казань: Татарское книжное издательство, 2011. 343 с.

\title{
НАКИ ИСАНБЕТ - ПЕРЕВОДЧИК РУССКОЙ КЛАССИЧЕСКОЙ ЛИТЕРАТУРЫ
}

\author{
Ринат Ферганович Бекметов, \\ Казанский федеральный университет, \\ Россия, 420008, г. Казань, ул. Кремлевская, д. 18, \\ bekmetov@list.ru.
}

\begin{abstract}
В статье рассматривается переводческая деятельность Наки Исанбета. В качестве материала для анализа были взяты его переводы произведений русской классической литературы, в частности отдельные фрагменты из переводов «Бахчисарайского фонтана» и «Полтавы» А. С. Пушкина. Были затронуты вопросы культурно-идеологического контекста обращения к русской классике, технического новаторства в сравнении с предшественниками, а также проблемы, связанные с принципами переводческой работы мастера. Важными составными элементами стиля Наки Исанбета как переводчика являются точность передачи смыслов оригинала, соответствие нового, переводного текста нормам родного (татарского) языка, его эстетическим приемам, глубина проникновения в воображаемый мир русской словесности. Тема, безусловно, требует дальнейшего исследования.
\end{abstract}

Ключевые слова: Наки Исанбет, русская литература, татарский язык, художественный перевод, сравнение и сопоставление, смысловые трансформации. 